\title{
Immunopharmacological Studies on TBX, a New Antiallergic Drug (4) Effects on Type II to IV Allergic Reactions and Immunological Functions in Animal Models
}

\author{
Yukiyoshi YANAGIHARA, Hiroshi KASAI ${ }^{1}$, Toshio KAWASHIMA ${ }^{1}$ \\ and Kenji NINOMIYA ${ }^{1}$ \\ Clinical Research Center for Allergy. National Sagamihara Hospital. \\ Sagamihara, Kanagawa 228. Japan \\ 'Research Laboratories, Tokyo Tanabe Pharmaceutical Co., Ltd., \\ Akabane-kita, Kita-ku, Tokyo 115, Japan
}

Accepted May 22, 1988

\begin{abstract}
The effects of 9 -methyl-3-(1H-tetrazol-5-yl)-4H-pyrido[1,2-a]pyrimidin4-one potassium salt (TBX) on type $\|$ to IV allergic reactions and immunological functions were investigated in animal models. Types II to IV allergic reactions in rodents were unaffected in vivo by TBX, even at higher doses than those capable of completely inhibiting the type I allergic reaction. However, both complementmediated hemolysis via the classical pathway and hypotonic shock-induced hemolysis were slightly inhibited in vitro only by a high concentration of the drug $\left(10^{-4}\right.$ $\mathrm{g} / \mathrm{ml}$ ). In the mouse system, TBX had no ability to suppress anti-hapten IgE antibody formation as well as hemagglutinin formation and to inhibit the proliferation of spleen cells induced by non-specific $T$ and $B$ cell mitogens. The results obtained indicate that TBX is an antiallergic drug essentially devoid of inhibitory actions on types II to IV allergic reactions and immunological functions, thus indicating that it is a specific inhibitor of type 1 allergic reactions.
\end{abstract}

In the previous papers (1-4), 9-methyl-3$(1 \mathrm{H}$-tetrazol-5-yl) - $4 \mathrm{H}$ - pyrido[1,2-a]pyrimidin-4-one potassium salt (TBX) has been reported to be a potent inhibitor of the release of pharmacologically active substance. such as histamine and slow reacting substance of anaphylaxis, responsible for the induction of the type I allergic reaction classified by Coombs and Gell (5). The antiallergic actions of the drug on passive cutaneous anaphylaxis (PCA) and experimental asthma in animals result entirely from the inhibition of the release of chemical mediators. However. there is no information as to whether TBX affects type II to IV allergic reactions.

In the present study, the effects of TBX on types II to IV allergic reactions were investigated in animal models. The results obtained indicate that TBX has no inhibitory effect on types II to IV allergic reactions. Experiments on the influences of the drug on immunogical functions were also performed in the mouse system in view of possible side effects.

\section{Materials and Methods}

\section{Drugs}

TBX (Tokyo Tanabe), dexamethasone (Sigma), 6-amidino-2-naphthyl-4-guanidino benzoate (FUT-175, Torii) and cyclophosphamide (CP. Sigma) were used. They were dissolved or suspended in physiological saline. Animals

The animals used were male Wistar rats weighing 200 to $300 \mathrm{~g}$. male Hartley guinea pigs weighing 300 to $400 \mathrm{~g}$. male Albino rabbits weighing approx. $2 \mathrm{~kg}$ and male ICR. and $B A L B / C$ and $B D F_{1}$ mice of 7 to 9 weeks of age. Rats and mice were purchased from Shizuoka Laboratory Anima! Center and guinea pigs and rabbits, from Tokyo Laboratory Animals.

\section{Antisera}

The following 3 antisera against sheep red blood cells (SRBC, Nippon Bio Test), rat 
surum and ovalbumin (OA. Seikagaku Kogyo) were produced in rabbits. According to the method of Glovsky et al. (6), rabbit antiSRBC serum (hemolysin) was obtained from the animals which had been immunized by i.v. injections with $1 \times 10^{9} \mathrm{SRBC}$ each repeated 10 times at a 1 -day interval; the hemolysin titer of the antiserum obtained was 1:200. Rabbit anti-rat serum was taken from the animals that had been immunized by i.v. injections of $1 \mathrm{ml}$ of normal rat serum repeated 10 times at a 1-day interval in accordance with the method of Ungar et al. (7). Rabbit anti-OA serum was obtained from the animals that had been immunized by i.m. injections with $2 \mathrm{ml}$ of an emulsion of $1 \mathrm{mg} \mathrm{OA}$ and complete Freund's adjuvant (Difco) repeated 4 times at a 1 -week interval. All the antisera were heated at $56{ }^{\circ} \mathrm{C}$ for $30 \mathrm{~min}$.

Type II allergic reaction

1) Complement-mediated or hypotonic shock-induced hemolysis: With regard to complement-mediated hemolysis via the classical pathway, it was performed according to the method of Mori et al. (18). Briefly, the mixture consisting of $0.5 \mathrm{ml}$ of SRBC previously sensitized with diluted hemolysin at a concentration of $1 \times 10^{9}$ cells $/ \mathrm{ml}, 1 \mathrm{ml}$ of diluted guinea pig serum, $1 \mathrm{ml}$ of drug solution and $5 \mathrm{ml}$ of gelatin veronal buffer were incubated at $37^{\circ} \mathrm{C}$ for $1 \mathrm{hr}$; and then the reaction was stopped by cooling. The mixture was centrifuged at $450 \times \mathrm{g}$ for $10 \mathrm{~min}$, and the absorbance of the sucernatant was read at $540 \mathrm{~nm}$. Similarly, hypotonic shock-induced hemolysis was investigated using the mixtures of $0.5 \mathrm{ml}$ of non-sensitized SRBC $\left(1 \times 10^{9}\right.$ cells $/ \mathrm{ml}$ ). $1.2 \mathrm{ml}$ of physiological saline, $1 \mathrm{ml}$ of drug solution and $4.8 \mathrm{ml}$ of $60 \mathrm{mM} \mathrm{NaCl}$ solution.

2) Systemic Forssman shock in guinea pigs: The reaction was induced by the i.v. injection of $1 \mathrm{ml} / \mathrm{kg}$ of rabbit anti-SRBC serum into guinea pigs as described Glovsky et al. (6), and the lethal time was measured. The complement activity mediated by the classical pathway ( $\mathrm{CH} 50)$ in the serum was also determined before and after the injection of the antiserum according to the method of Mayer (9).

3) Reversed cutaneous anaphylaxis in rats: This experiment was performed according to the method of Ungar et al. (7). Briefly, $0.05 \mathrm{ml}$ of rabbit anti-rat serum at $1 / 4$ dilution was injected intradermally into the shaved back of rats. The animals were killed $2 \mathrm{hr}$ after the injection, the inflamed sites of skin were punched out (the hole being $12 \mathrm{~mm}$ in diameter), and the weights of the pieces of skin were measured. The skin areas injected with physiological saline were also weighed. Type III allergic reaction

1) Passive Arthus reaction in guinea pigs: Guinea pigs were passively sensitized with the i.v. injection of $1 \mathrm{mg} / \mathrm{kg}$ of rabbit anti-OA serum at $1 / 8$ dilution. After $30 \mathrm{~min}, 0.2 \mathrm{ml}$ of $2.5 \%$ OA solution was injected intradermally into the shaved back of each animal. The dimension of the inflamed sites of skin were macroscopically determined with the time course.

2) Reversed Arthus reaction in rats: Rats received the i.v. injection of $2 \mathrm{ml} / \mathrm{kg}$ of $2 \%$ of OA solution. After $30 \mathrm{~min}, 0.1 \mathrm{ml}$ rabbit anti$\mathrm{OA}$ serum at $1 / 2$ dilution was injected intradermally into the shaved back of each animal. The animals were killed at 1, 2, 4, 8 and $24 \mathrm{hr}$ after the provocation, the inflamed sites of skin were punched out (the hole being $12 \mathrm{~mm}$ in diameter), and the weights of the pieces of skin were measured. The skin areas injected with physiological saline were also weighed.

\section{Type IV allergic reaction}

1) Tuberculin reaction in guinea pigs: Guinea pigs were immunized by the i.m. injection of $1 \mathrm{mg}$ of Bacillus Calmette-Guerin (BCG, Nippon BCG). After 31 days, the reaction was elicited by the intradermal (i.d.) injection of $0.5 \mu \mathrm{g}$ of purified protein derivatives (PPD. Nippon BCG) into the shaved back of each animal. The animals showing a diameter of induration of more than $10 \mathrm{~mm}$ at $24 \mathrm{hr}$ after the provocation were selected and challenged again with the same antigen at 7 days after the previous provocation.

2) Tuberculin reaction in mice: ICR mice were immunized with the s.c. injection of $1 \mathrm{mg}$ of $B C G$. After 14 days, the reaction was induced by the i.d. injection of $10 \% \mathrm{~g}$ of PPD into the right foot pad of each animal. The foot pad swelling was determined by a dial thickness gauge (Ozaki Factory) at $24 \mathrm{hr}$ after the challenge. The left foot pad injected 
with physiological saline was also measured.

3) Contact dermatitis in mice: ICR mice were sensitized by applying 2 times once a day to the skin of their abdomen $20 \mu$ of 2,4dinitro fluorobenzene (DNFB. Tokyo Kasei) at a concentration of $0.5 \%$ in acetone-olive oil. After 4 days, the animals were challenged with $10 / \mathrm{l} /$ ear of $0.2 \%$ antigen solution in acetone-olive oil applied to both ears. The ear thickness was determined by a dial thickness gauge immediately before and at $24 \mathrm{hr}$ after the challenge.

\section{Antibody formation and cell proliferation}

1) Hemagglutinin formation in mice: $B D F_{1}$ mice were immunized with the i.v. injection of $0.2 \mathrm{ml}$ of $2 \%$ SRBC suspension. Blood was collected from the retroorbital venus plexus on the 5 th and 10th day after the immunization. The antisera obtained from 5 animals were pooled and heated at $56^{\circ} \mathrm{C}$ for $30 \mathrm{~min}$. It was diluted serially with physiological saline for measuring the hemagglutinin titer, which was estimated by the microplate method.

2) Anti-DNP $\lg E$ antibody formation in mice: BALB/c mice were immunized with the i.p. injection of $1 \mu \mathrm{g}$ of $O A$ coupled with the 2.4-dinitrophenyl group (DNP-OA) absorbed on $\mathrm{Al}(\mathrm{OH})_{3}$ gel (alum), according to the method of Lee and Sehon (10). Blood was collected from the retroorbital venus plexus at a 1 -week interval, and the antisera from 5 animals were pooled. The anti-DNP $\lg E$ antibody titer of the serum was determined by 24 -hr heterologous PCA in rats. PCA was elicited by the i.v. injection of $1 \mathrm{ml}$ of physiological saline containing $2.5 \mathrm{mg}$ DNP. conjugated bovine serum albumin and $5 \mathrm{mg}$ of Evans blue. The PCA titer was expressed as the maximal dilutions showing a positive bluing spot (more than $5 \mathrm{~mm}$ in diameter).

3) Proliferation of mouse spleen cells: Spleen cells from normal BALB/c mice were suspended in RPMI 1640 supplemented with $10 \%$ heat-inactivated fetal calf serum (Gibco). 100 unit $/ \mathrm{ml}$ of penicillin, $100 \mu \mathrm{g} / \mathrm{ml}$ of streptomycin and $5 \mathrm{mM}$ of L-glutamine. Each well of a tissue culture microplate (Falcon 3072 ) contained $2 \times 10^{5}$ viable cells in a volume of $0.2 \mathrm{ml}$ and was incubated at $37^{\circ} \mathrm{C}$ for 3 days in a $5 \% \mathrm{CO}_{2}$ incubator in the absence or presence of non-specific mitogens. Final concentrations of concanavalin A (Con A. Sigma), phytohemagglutinin-P (PHA-P, Serva), lipopolysaccharide from Escherichia coli (LPS, Sigma) and pokeweed mitogen (PWM. Sigma) were $2.5 \mu \mathrm{g} / \mathrm{ml}, 25 \mu \mathrm{g} / \mathrm{ml}, 25$ $\mu \mathrm{g} / \mathrm{ml}$ and $0.5 \mu \mathrm{g} / \mathrm{ml}$, respectively. ${ }^{3} \mathrm{H}$ Thymidine ( ${ }^{3} \mathrm{H}-\mathrm{TdR}$, Amersham) was then added to each well $(18.5 \mathrm{KBq} /$ well), followed by an additional incubation for $12 \mathrm{hr}$. The cells were harvested on a glass filter, and the radioactivity was determined by a liquid scintillation counter (Aloka LSC-653).

\section{Statistical analysis}

Results were expressed as the meantS.E. Statistical significance was determined by Student's $t$-test.

\section{Results}

\section{Type II allergic reaction}

1) Complement-mediated and hypotonic shock-induced hemolysis: The results are summarized in Table 1. Complement-mediated hemolysis via the classical pathway was not affected by $10^{-7}$ to $10^{-5} \mathrm{~g} / \mathrm{ml}$ of TBX, but it was significantly inhibited by $10^{-4} \mathrm{~g} / \mathrm{ml}$ of the drug $(P<0.01)$. Similar results were obtained in hypotonic shock-induced hemolysis.

Table 1. Effect of TBX on complement-mediated and hypotonic shock-induced hemolysis

\begin{tabular}{lccc}
\hline Drug & $\begin{array}{c}\text { Concentration } \\
(\mathrm{g} / \mathrm{ml})\end{array}$ & $\begin{array}{c}\text { Complement-mediated } \\
\text { hemolysis } \\
(\%)\end{array}$ & $\begin{array}{c}\text { Hypotonic shock-induced } \\
\text { hemolysis } \\
(\%)\end{array}$ \\
\hline Control & - & $34.7 \pm 0.8$ & $57.3 \pm 0.4$ \\
TBX & $10^{-7}$ & $33.0 \pm 0.2$ & $56.6 \pm 0.2$ \\
& $10^{-6}$ & $33.3 \pm 0.1$ & $56.7 \pm 0.1$ \\
& $10^{-5}$ & $33.8 \pm 0.5$ & $57.1 \pm 0.4$ \\
\hline $10^{-4}$ & $30.5 \pm 0.6^{* *}$ & $49.2 \pm 0.2^{* *}$ \\
\hline
\end{tabular}

Each value represents the mean \pm S.E. of 5 or 6 experiments. **: Statistically significant difference from the control at $P<0.01$. 
Note that a high concentration of TBX was needed to induce the inhibition of both types of hemolysis and that such inhibition was no more than by approx. $10 \%$.

2) Systemic Forssman shock in guinea pigs: Animals were treated with TBX or FUT. 175 immediately before the i.v. injection of rabbit anti-SRBC serum. As shown in Table 2. TBX (1 to $25 \mathrm{mg} / \mathrm{kg}$, i.v.) inhibited neither systemic Forssman shock nor a decrease in the complement activity of the serum. In contrast, FUT-175, known to be a strong anticomplement agent (11). completely protected against this shock and significantly inhibited the decrease in the complement activity of the serum $(P<0.05)$.

3) Reversed cutaneous anaphylaxis in rats: As indicated in Table 3. TBX (0.01 to 0.25 $\mathrm{mg} / \mathrm{kg}$. i.v.), administered immediately before the i.d. administration of rabbit anti-rat serum. did not inhibit reversed cutaneous anaphylaxis in rats, whereas FUT-175 (1 mg/kg, i.v.) significantly inhibited the reaction $(P<0.05)$. Type III allergic reaction

1) Passive Arthus reaction in guinea pigs: TBX (1 to $25 \mathrm{mg} / \mathrm{kg}$, i.v.) and dexamethasone
(10 mg/kg. i.p.) were administered immediately and $60 \mathrm{~min}$ before the antigen challenge, respectively. As illustrated in Fig. 1. TBX did not inhibit the passive Arthus reaction. whereas dexamethasone significantly inhibited the reaction at the late phase $(6$ to 24 hr, $P<0.05$ or $P<0.01$ ).

2) Reversed Arthus reaction in rats: $T B X$ $(0.01$ to $0.25 \mathrm{mg} / \mathrm{kg}$, i.v.) and dexamethasone $(10 \mathrm{mg} / \mathrm{kg}$, i.p.) were administered immediately and $60 \mathrm{~min}$ before the i.d. injection of anti-OA serum, respectively. As shown in Fig. 2. TBX did not inhibit the reversed cutaneous reaction in rats, while dexamethasone clearly inhibited this reaction.

\section{Type IV allergic reaction}

The tuberculin reaction and contact dermatitis were induced in guinea pigs or mice. TBX and dexamethasone were administered immediately before the antigen challenge. The former was given i.v. at 1 to $25 \mathrm{mg} / \mathrm{kg}$ to guinea pigs and at 0.01 to $0.25 \mathrm{mg} / \mathrm{kg}$ to mice. The latter was administered i.p. at 10 $\mathrm{mg} / \mathrm{kg}$ to guinea pigs and at $5 \mathrm{mg} / \mathrm{kg}$ to mice. The results are summarized in Table 4. Neither the tuberculin reaction in guinea pigs

Table 2. Effect of TBX and FUT-175 on systemic Forssman shock in guinea pigs

\begin{tabular}{|c|c|c|c|c|}
\hline Drug & $\begin{array}{c}\text { Dose } \\
(m g / k g, i . v .)\end{array}$ & $\begin{array}{l}\text { No. of animals } \\
\text { (survived/total) }\end{array}$ & $\begin{array}{l}\text { Lethal time } \\
\text { (sec) }\end{array}$ & $\begin{array}{c}\text { Complement activity } \\
(\% \text { decrease })\end{array}$ \\
\hline Control & - & $0 / 6$ & $204 \pm 29$ & $29.6 \pm 2.0$ \\
\hline \multirow[t]{3}{*}{ TBX } & 1 & $0 / 6$ & $170 \pm 25$ & $32.8 \pm 2.0$ \\
\hline & 5 & $0 / 6$ & $226 \pm 13$ & $29.0 \pm 2.2$ \\
\hline & 25 & $0 / 5$ & $178 \pm 27$ & $23.0 \pm 2.2$ \\
\hline FUT-175 & 5 & $6 / \hat{0}$ & No death after $24 \mathrm{hr}$ & $16.7 \pm 5.2^{*}$ \\
\hline
\end{tabular}

TBX and FUT- 175 were administered i.v. immediately before the challenge with rabbit anti-SRBC serum. $\mathrm{CH} 50$ in the serum was determined before the challenge and immediately after death in animals treated with physiological saline or TBX and at $60 \mathrm{~min}$ after the challenge in animals given FUT-175. CH50 was $201 \pm 6 \mathrm{~J} / \mathrm{ml}$ in animals treated with no antiserum. Each value represents the mean $\pm S$.E. of 5 or 6 animals.

*: Statistically significant difference from the control at $P<0.05$.

Table 3. Effect of TBX and FUT-175 on reversed cutaneous anaphylaxis in rats

\begin{tabular}{lcc}
\hline Drug & $\begin{array}{c}\text { Dose } \\
(\mathrm{mg} / \mathrm{kg}, \mathrm{i.v})\end{array}$ & $\begin{array}{c}\text { Swelling } \\
(\%)\end{array}$ \\
Control & - & $51.0 \pm 4.3$ \\
TBX & 0.01 & $42.4 \pm 6.5$ \\
& 0.05 & $40.2 \pm 3.7$ \\
FUT-175 & 0.25 & $42.5 \pm 4.2$ \\
\hline
\end{tabular}

TBX and FUT-175 were given i.v. immediately before the challenge with rabbit anti-rat serum. Each value represents the mean \pm S.E. of 6 animals. ": Statistically significant difference from the control at $P<0.05$. 


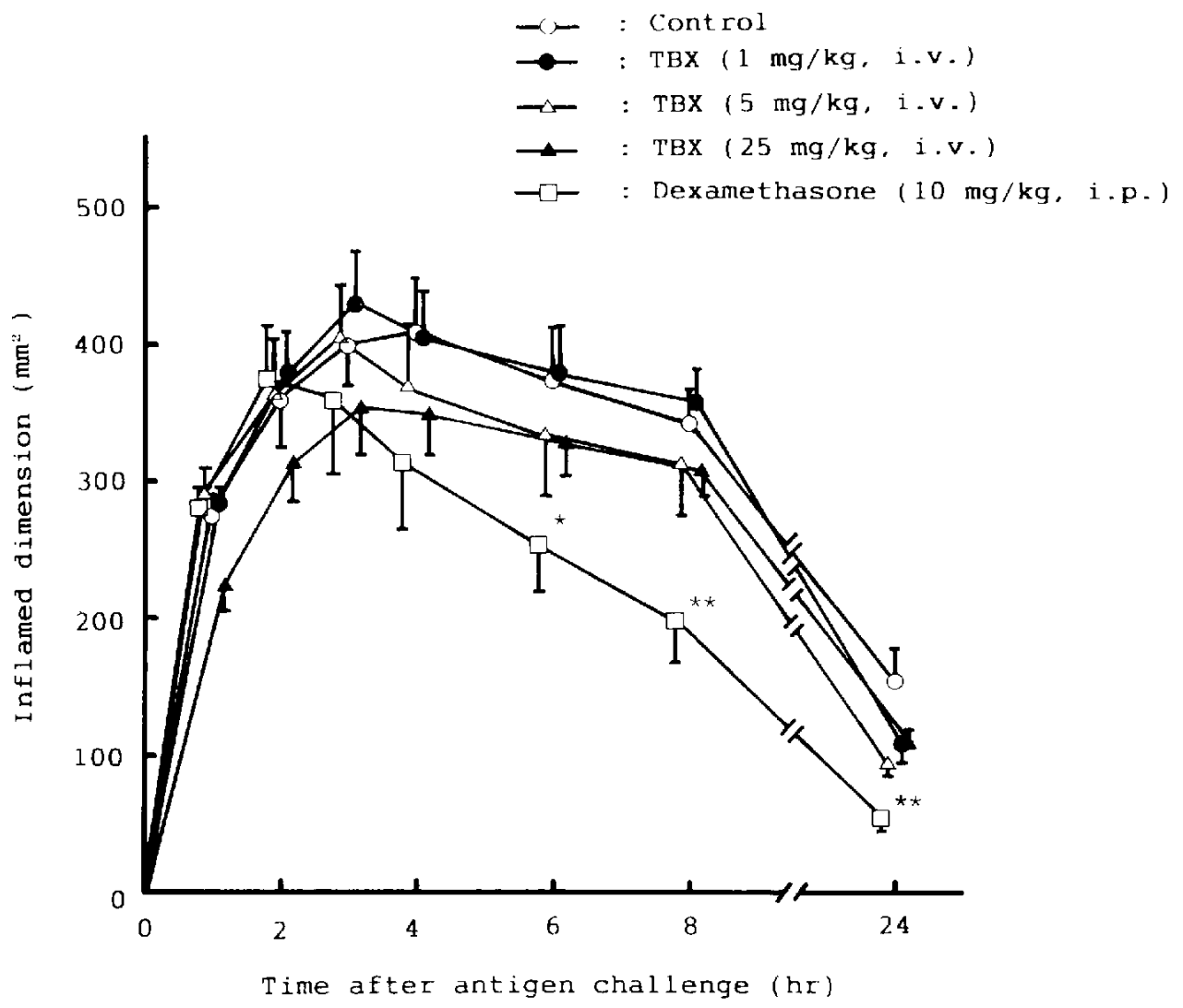

Fig. 1. Effect of $T B X$ and dexamethasone on the passive Arthus reaction in guinea pigs. TBX and dexamethasone were given i.v. immediately and i.p. $60 \mathrm{~min}$ before the antigen challenge, respectively. Each point represents the mean \pm S.E. of 6 animals. * **: Statistically significant difference from the control at $P<0.05$ and $P<0.01$, respectively.

and mice nor contact dermatitis in mice was inhibited by TBX. In contrast, dexamethasone significantly inhibited the reactions $(P<0.01)$. Antibody formation and cell proliferation

1) Hemagglutinin formation in mice: $T B X$ (1 to $100 \mathrm{mg} / \mathrm{kg} /$ day, p.o.) was administered for 5 days before or after the immunization with SRBC. The hemagglutinin titer in the control group was $1: 160$ at 5 days after the immunization. The antibody formation against SRBC was not suppressed by TBX, regardless of the administration time and dose. In contrast, CP. which was given at $20 \mathrm{mg} / \mathrm{kg} /$ day. i.p., for 5 days after the immunization, strongly suppressed this antibody formation (less than 1:10 of hemagglutinin titer).

2) Anti-DNP $\operatorname{lgE}$ antibody formation in mice: TBX (1 to $100 \mathrm{mg} / \mathrm{kg} /$ day, p.o.) was administered for 7 days before or after the immunization. The PCA titer of anti-DNP IgE antibody in the control group was 1:1024 at 14 days after the immunization. Anti-DNP $\operatorname{IgE}$ antibody formation was not suppressed by $T B X$, regardless of the administration time and dose. However, $\mathrm{CP}$, which was given at $20 \mathrm{mg} / \mathrm{kg} /$ day, i.p., for 5 days after the $\mathrm{im}$ munization, clearly suppressed $\lg \mathrm{E}$ antibody formation (1:160 of the PCA titer of anti-DNP IgE antibody).

3) Proliferation of mouse spleen cells: The effect of TBX on the cell viability was preliminarily investigated in spleen cells taken from normal mice. Although the data are not shown, cultures of spleen cells in the presence of TBX at concentrations less than $1 \mu \mathrm{g} / \mathrm{ml}$ for 3 days resulted in little or no changes in 


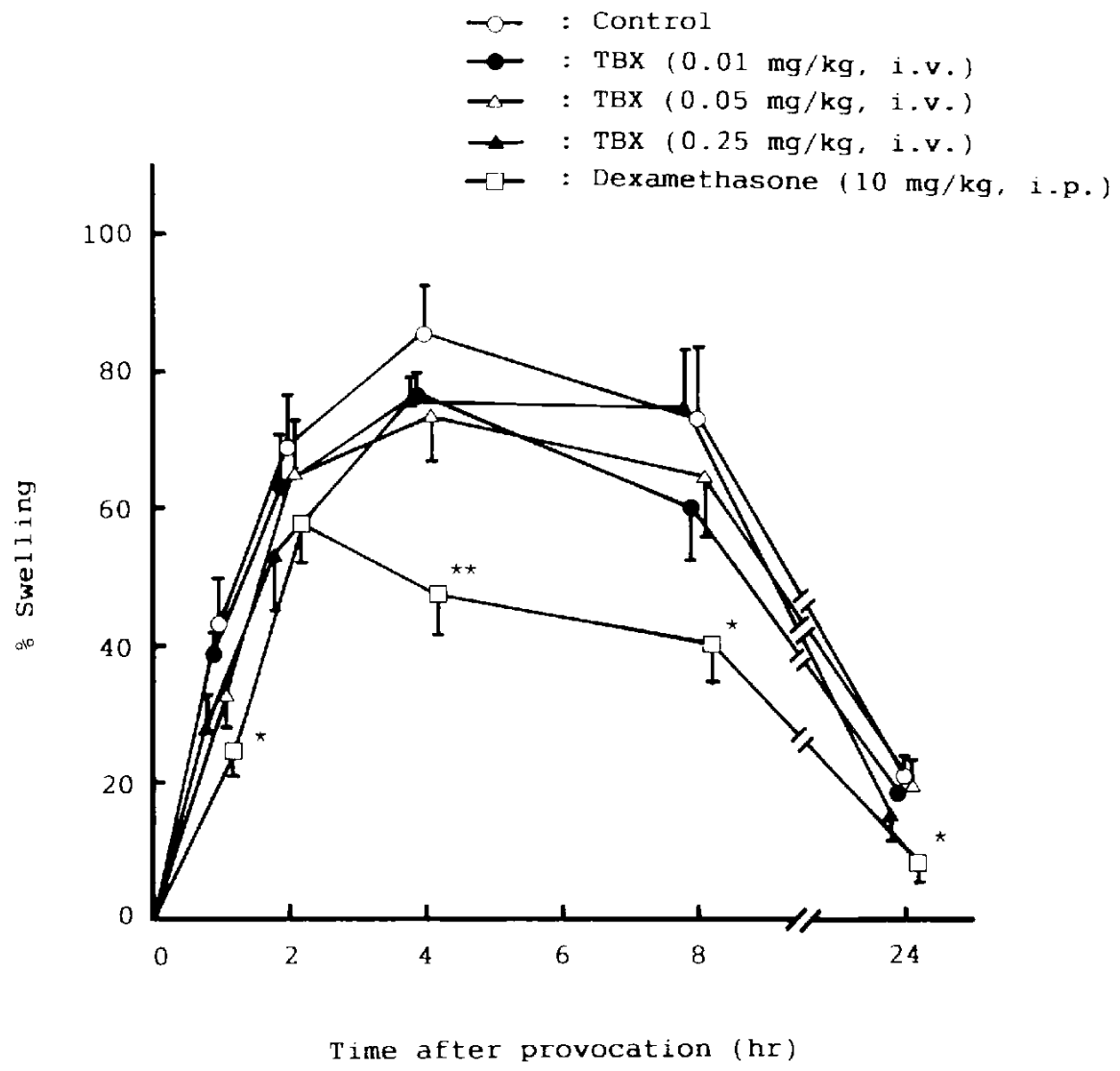

Fig. 2. Effect of TBX and dexamethasone on the reversed Arthus reaction in rats. TBX and dexamethasone were given i.v. immediately and i.p. at 60 min before the provacation, respectively. Each point represent the mean \pm S.E. of 6 animals. $\quad{ }^{* *}$. Statistically significant difference from the control at $P<0.05$ and $P<0.01$, respectively.

Table 4. Effect of TBX and dexamethasone on tuberculin reaction and contact dermatitis in guinea pigs or mice

\begin{tabular}{|c|c|c|c|c|}
\hline \multirow{2}{*}{ Drug } & \multirow{2}{*}{$\begin{array}{c}\text { Dose } \\
(\mathrm{mg} / \mathrm{kg})\end{array}$} & $\begin{array}{c}\text { Tuberculin reaction } \\
\text { (guinea pig) }\end{array}$ & $\begin{array}{l}\text { Tuberculin reaction } \\
\text { (mouse) }\end{array}$ & $\begin{array}{c}\text { Contact dermatitis } \\
\text { (mouse) }\end{array}$ \\
\hline & & $\begin{array}{c}\text { Diameter of indura- } \\
\text { tion }(\mathrm{mm})\end{array}$ & $\begin{array}{l}\text { Footpad swelling } \\
\qquad\left(\times 10^{-2} \mathrm{~mm}\right)\end{array}$ & $\begin{array}{c}\text { Increase in ear } \\
\text { thickness } \\
\left(\times 10^{-2} \mathrm{~mm}\right) \\
\end{array}$ \\
\hline Control & - & $15.9 \pm 0.53$ & $61.7 \pm 6.5$ & $12.7 \pm 2.3$ \\
\hline \multirow[t]{3}{*}{ TBX } & $1(0.01)$ & $17.1 \pm 0.86$ & $51.6 \pm 6.2$ & $11.4 \pm 2.8$ \\
\hline & $5(0.05)$ & $16.2 \pm 0.61$ & $72.2 \pm 10.1$ & $11.2 \pm 2.1$ \\
\hline & $25(0.25)$ & $15.1 \pm 0.69$ & $52.8 \pm 8.6$ & $10.4 \pm 1.9$ \\
\hline Dexamethasone & $10(5)$ & $13.2 \pm 0.48^{* *}$ & $33.0 \pm 5.6^{* *}$ & $3.1 \pm 0.6^{* *}$ \\
\hline
\end{tabular}

The value in parentheses indicates the administration dose of the drugs in rice. TBX and dexamethasone were administered i.v. and i.p. immediately before the antigen challenge, respectively. Measurement was performed $24 \mathrm{hr}$ after the challenge. Each value represents the mean \pm S.E. of 8 to 11 animals. ** Statistically significant difference from the control at $P<0.01$. 
Table 5. Effect of TBX on cell proliferation induced by Con A, PHA-P, LPS and PWM

\begin{tabular}{lrr}
\hline & \multicolumn{2}{c}{${ }^{3} H-T d R$ uptake $(d p m)$} \\
\cline { 2 - 3 } Mitogen & \multicolumn{1}{c}{ Control } & TBX \\
Con A & $207111 \pm 9375$ & $211439 \pm 22808$ \\
PHA -P & $20512 \pm 480$ & $24287 \pm 2956$ \\
LPS & $13317 \pm 1221$ & $15962 \pm 2840$ \\
PWM & $4428 \pm 207$ & $4824 \pm 312$ \\
\hline
\end{tabular}

Spleen cells from normal mice were cultured in the absence or presence of $1 \mu \mathrm{g} / \mathrm{mil}$ of TBX with each nonspecific mitogen. Each value represents the mean $\pm S$.E. of triplicate cultures.

the cell viability. One $\mu \mathrm{g} / \mathrm{m} /$ of the drug was consequently chosen for the investigation of the effect on non-specific mitogen-induced cell proliferation. The results are summarized in Table 5. TBX exerted no inhibitory influences on the cell proliferation induced by Con A. PHA-P, LPS and PWM.

\section{Discussion}

In the previous papers (1-3), TBX, showing no antagonistic actions on chemical mediators, has been reported to be a new antiallergic drug capable of strongly inhibiting type I allergic models such as PCA and experimental asthma through the inhibition of mediator release from mast cells. The present study was designed to investigate the effects on type II to IV allergic reactions and immunological functions in animal models. The results obtained clearly indicate that none of them are affected by TBX.

With regard to in vivo types $I I$ to IV allergic reactions, they were not inhibited by TBX. For example. systemic Forssman shock in guinea pigs and reversed cutaneous anaphylaxis in rats (type (1), passive and reversed Arthus reactions in guinea pigs or rats (type |II), and tuberculin reaction and contact dermatitis in guinea pigs or mice (type IV) were unaffected by the drug, regardless of the administration dose. It should be emphasized that in these experiments, higher doses were used than those inducing the complete inhibition of IgE-mediated rat and guinea pig homologous PCAs. In fact, animals were treated with the i.v. administration of 0.01 to $0.25 \mathrm{mg} / \mathrm{kg}$ (rat and mouse) and 1 to $25 \mathrm{mg} / \mathrm{kg}$ (guinea pig) of TBX, since the ID50 values of the drug (i.v.) have been reported to be $7 \mu \mathrm{g} / \mathrm{kg}$ in the rat $P C A$ and $920 \mu \mathrm{g} / \mathrm{kg}$ in the guinea pig $P C A$. respectively (1). It was also demonstrated that in contrast to FUT-175, one of the potent anticomplement agents (11). TBX did not inhibit a decrease in the complement activity of the serum of guinea pigs with systemic Forssman shock, suggesting that it exerts no inhibitory influence on serum complement. Indeed, TBX at concentrations less than $10^{-5}$ $\mathrm{g} / \mathrm{ml}$ showed no inhibition of complementmediated hemolysis in vitro via the classical pathway. However, $10^{-4} \mathrm{~g} / \mathrm{ml}$ of the drug induced a significant but slight inhibition of the reaction (approx. 10\%). Similar results were obtained in hypotonic shock-induced hemolysis with the same treatment. Note that the coricentrations of TBX required to inhibit both types of hemolysis were apparently much too high compared with its IC50 (5.1x $10^{-9} \mathrm{~g} / \mathrm{ml}$ ) in $\mathrm{lg} E$-mediated histamine release from rat mast cells (2). It could thus be suggested that the inhibition of hemolysis by a high concentration of this drug might be attributed to a non-specific mechanism.

The data further demonstrate that TBX shows no suppressive effects on the antibody responses to $T$ cell-dependent antigens. For instance, neither hemagglutinin formation in mice immunized with SRBC nor anti-hapten IgE antibody formation in mice immunized with DNP-OA and alum was suppressed by the p.o. administration of TBX (1 to $100 \mathrm{mg} /$ $\mathrm{kg} /$ day). These results strongly suggest that $\mathrm{T}$ and $\mathrm{B}$ cell functions responsible for immune responses, regardless of the immunoglobulin class, were unaffected by TBX. Indeed, the in vitro proliferation of mouse spleen cells induced by Con A, PHA-P. LPS and PWM was not inhibited by $1 \mu \mathrm{g} / \mathrm{ml}$ of $\mathrm{TBX}$, which exerted little or no influence on the cell viability, indicating that TBX does not inter- 
fere with lymphocyte functions. From the results that $T B X$ caused no inhibition of the cell proliferation induced by Con A. PHA-P and PWM, known to be macrophage/ monocyte-dependent mitogens $(12,13)$, it was also suggested that the drug had no inhibitory activity on macrophage/monocyte functions such as antigen presentation. However, it is likely that high concentrations of TBX may induce the non-specific inhibition of the cell proliferation, since mitogenic responses to all the mitogens were clearly inhibited by the drug at concentrations higher than $1 \mu \mathrm{g} / \mathrm{ml}$ (data not shown).

In summary. TBX is a new compound essentially devoid of inhibitory actions on types II to IV allergic reactions in animal models, and its antiallergic action is specific for the type I allergic reaction. In addition, it is suggested that in the mouse system. TBX has no ability to suppress the antibody responses, regardless of the immunoglobulin class, and it does not interfere with $T$ and $B$ cell functions either. These properties of TBX may be desirable for its clinical application.

\section{References}

1 Yanagihara, Y., Kasai, H., Kawashima, T. and Shida, T.: Immunopharmacological studies on TBX, a new antiallergic drug. (1) Inhibitory effects on passive cutaneous anaphylaxis in rats and guinea pigs. Japan. J. Pharmacol. 48, $91-$ 101 (1988)

2 Yanagihara, Y., Kasai, H. and Shida, T.: Immunopharmacological studies on TBX, a new antiallergic drug. (2) Inhibitory effects on histamine release from peritoneal mast cells and lung fragments of rats. Japan. J. Pharmacol. 48, 103$112(1988)$

3 Yanagihara, Y., Kasai, H, Matsui, S. and Ninomiya, K:: Immunopharmacological studies on TBX, a new antiallergic drug. (3) Inhibitory effects on histamine release from lung fragments and bronchoconstriction in guinea pigs. Japan. J. Pharmacol. 51, 83-92 (1989)

4 Kawashima, T., Tomioka, $H$. and Yoshida, S.: inhibition of chemical mediator release from human leukocytes and lung fragments by TBX. Japan. J. Allergol. 37, 438-447 (1988) (Abs. in English)

5 Coombs, R.R.A. and Gell, P.G.H.: Classification of allergic reactions responsible for clinical hypersensitivity and disease. In Clinical Aspect of Immunology. 3rd ed., Edited by Geli, P.G.H., Coombs, R.R.A. and Lachmann. P.J., p. 761781. Blackwell Scientific Pubication, Oxford (1975)

6 Glovsky, M.M., Ward, P.A., Becker, E.L. and Halbrock, N.J.: Role of fumaropimaric acid in guinea pig complement dependent and noncomplement dependent biologic reactions. I Inhibition of Forssman, reversed passive Arthus, and PCA reactions by fumaropimaric acid. J. Immunol. 102, 1-14 (1969)

7 Ungar, G., Kobrin, S. and Sezesny, B.R.: Measurement of inflammation and evaluation of antiinflammatory agents. Arch. Int. Pharmacodyn. Ther. 123, 71-77 (1959)

8 Mori, T., Onsugi, Y., Furuno, K., Takaku, S., Matsuno, T., Suzuki, S., Koyama, K., Shindo, M. and Takagaki, Y.: Inhibitory effect of aminobenzoic acid derivatives on hemolytic reaction in vitro. Yakugaku Zasshi 95. 1477-1482 (1975) (Abs. in English)

9 Mayer, M.M.: Complement and complement fixation. Experimental Immunochemistry, 2nd ed., Edited by Kabat, E.A. and Mayer, M.M., p. 133240. Charles C. Thomas Publisher, Springfield. Illinois (1961)

10 Lee, W.Y. and Sehon, A.H.: Suppression of reaginic antibody formation. I. Induction of hapten-specific tolerance. J. Immunol. 114, 829-836 (1975)

11 Hitomi, $Y$. and Fujii, S.: Inhibition of various immunological reactions in vivo by a new synthetic complement inhibitor. Int. Aich. Allergy Appl. Immunol. 69, 262-267 (1982)

12 Alevy, Y.G. and Battisto, J.R.: Dextran-triggered $T$ cells heighten $T$ - and $B$-cell reactions to mitogens. Immunology 30, 379-390 (1976)

13 Rosenberg, S.A. and Lipsky, P.E.: Monocyte dependence of pokeweed mitogen-induced differentiation of immunoglobulin-secreting cells from human peripheral blood mononuclear cells. J. Immunol. 122, 926-931 (1979) 